\title{
El cuerpo del rey: poder y legitimación en la monarquía hispánica
}

The Body of King: Power and Legitimation in the Hispanic Monarchy

Este es un artículo de revisión historiográfica que aborda la construcción del cuerpo del rey y de su imagen pública, para comprender luego la relación entre poder y legitimidad en la monarquía hispánica entre los siglos XVI y XVII. El artículo presenta los principales referentes historiográficos sobre el tema y hace especial énfasis en los más recientes estudios de ceremoniales y etiquetas cortesanas. Siguiendo esta línea de investigación, la hipótesis de partida es que el sostenimiento de la monarquía hispánica no solo dependió de estrategias coercitivas, sino que estuvo determinado por la construcción de herramientas persuasivas (soft power), entre las que se encuentra la puesta en escena del rey, donde se creó en buena medida la percepción de consenso cultural dentro un vasto imperio transatlántico.

Palabras clave: monarquía hispánica, soft power, cuerpo del rey. 
This article is a historiographic review that approaches the construction of the body of the king and of his public image to understand the relation between power and legitimacy in the Hispanic Monarchy between the XVI ${ }^{\text {th }}$ to XVII ${ }^{\text {th }}$ centuries. The article presents the principal historiographics modals on the topic, doing special emphasis in the most recent studies of ceremonial and court labels.
Following this line of investigation, the hypothesis is that the maintenance of the Hispanic monarchy not only depended on coercive strategies but it was determined by the construction of persuasive tools (Soft Power), among others the putting in scene of the king, where there created mostly the perception of cultural consensus inside a vast transatlantic empire.

Keywords: Hispanic monarchy, soft power, body of king.

\section{Introducción ${ }^{1}$}

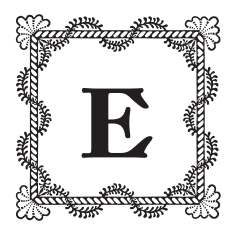

n los últimos años ha aparecido una copiosa producción académica que pretende desentrañar los mecanismos de construcción del poder. En una época marcada por la propaganda, los mass-media y el auge de la cultura visual y del espectáculo para legitimar el modelo económico y social, cada vez resultan más débiles aquellas lecturas que atribuyen todo el éxito del poder a la represión y a la coacción y han ido ganado aceptación modelos interpretativos más atentos a las formas persuasivas de legitimación.

Aunque los historiadores desconfiamos de las generalizaciones, podemos decir que, en todas las épocas, el uso exclusivo de la fuerza ha resultado ser costoso, desgastante y la mayoría de las veces un acto fallido en materia de

I Este artículo hace parte de la tesis doctoral "Fastos monárquicos en el Nuevo Reino de Granada: la imagen del rey y los intereses locales. Siglos XVI-XVIII" (20I4), Departamento de Historia Moderna, Universidad de Barcelona. Esta tesis fue realizada dentro del proyecto de investigación "Poder y representaciones en la Edad Moderna: la monarquía hispánica como campo cultural (I500-I800)”, Ministerio de Economía y Competitividad. Gobierno de España. Ref. HAR2012-39516. La autora desea agradecer a los demás miembros del grupo PyREM por sus valiosos comentarios en la elaboración de este trabajo, así como también a la historiadora Viviana Arce por sus observaciones del artículo. 
establecimiento o sostenimiento, según sea el caso, de un orden social. Por el contrario, la persuasión ha resultado tener enorme efectividad.

La inclusión de esta variable cultural y simbólica en la agenda de investigación ha beneficiado de manera notable los estudios sobre la época moderna. En España, este horizonte ha producido un considerable número de seminarios, publicaciones y proyectos de investigación en curso $^{2}$. Sin embargo, solo muy recientemente la historiografía americanista ha empezado a valorar el alcance que tuvo la implementación de ciertas prácticas y productos culturales para forjar la percepción de totalidad en los reinos transatlánticos de la monarquía hispánica, porque, en cualquier caso, esta no habría podido gobernar un territorio de dimensiones planetarias sin un mínimo de consenso cultural's

Según Louis Marin, el poder es ante todo estar en situación de ejercer una acción sobre algo o alguien, no actuar o hacer, sino tener la potencia, la reserva de una fuerza que no se gasta, sino que pone en estado de gastarse. En este orden de ideas, para ejercer el liderazgo político, no solo son necesarios el poder y la fuerza material del gobierno, sino también la aceptación más o menos voluntaria de los sujetos subordinados, mediada por las formas culturales que transmiten una manera particular de ver el mundo, la naturaleza y las relaciones humanas. Esto es lo que, en definitiva, Joseph Nye ha denominado soft power.

Es un hecho conocido que la centralización administrativa, el afianzamiento burocrático y la paulatina supresión de las formas feudales se vieron frenados en la práctica por los estamentos y las prerrogativas locales. La construcción y el mantenimiento de las monarquías no podían depender solamente de las victorias en el campo de batalla o de las alianzas dinásticas. La subordinación política de las autoridades locales — tanto en Europa como en América- se jugó también en el diseño y la puesta en marcha de ciertas estrategias políticas,

2 Para mencionar algunos de los puntos de investigación más importantes en este sentido, el Instituto Universitario La Corte en Europa (IULCE), bajo la dirección del profesor Manuel Rivero de la Universidad Autónoma de Madrid, que cuenta con la revista Libros de la Corte, especializada en el tema que nos ocupa. También merece resaltarse el grupo de investigación Iconografía i Història de l'Art (IHA), liderado por Víctor Mínguez de la Universidad Jaume I; la Red Columnaria, coordinada por José Javier Ruiz Ibáñez y Gaetano Sabatini; el Nodo Atlántico-Coredex/Polycentricstates, coordinado por Manuel Herrero Sánchez de la Universidad Pablo de Olavide, y el grupo de investigación Poder i Representacions, coordinado por Joan Lluis Palos del Departamento de Historia Moderna de la Universidad de Barcelona.

3 De esta línea de investigación se ocupa el proyecto de investigación "Poder y representaciones culturales en la época moderna. Siglos XVi-XviıI” (Ministerio de Economía y Competitividad. Gobierno de España. Ref. HAR20i6-78304), bajo la dirección de J. L. Palos. 
cuyas herramientas represivas y sugestivas fueron combinándose y evolucionando de manera acorde con las expectativas políticas del Imperio hispánico.

En los últimos años se han multiplicado los estudios sobre la propaganda política en la época moderna. Sin embargo, como bien lo advierte Peter Burke en su estudio sobre la fabricación de Luis XIV, resaltar las formas persuasivas que se utilizaron en el Antiguo Régimen no debe inducirnos a anacronismos. Resulta también fundamental huir de las posturas interpretativas más extremas. Si bien la cultura oficial estaba encaminada a facilitar el ejercicio de la autoridad, no se puede dar por hecho con demasiada facilidad que los receptores de este mensaje fueran manipulados (Burke 20).

Con esta consideración sobre la mesa, este artículo pretende abordar los aspectos más importantes en la construcción de la imagen del rey hispánico desde la etiqueta cortesana, buscando en la historia de este particular cuerpo la inevitable relación entre el poder y la legitimidad de la monarquía hispánica entre los siglos XVI y XVII.

\section{Un rey católico para un imperio transatlántico}

Como lo ha indicado Jacques Le Goff, la vida cotidiana en los albores de la época moderna tenía una enorme familiaridad con los aspectos sobrenaturales, de manera que la apropiación de estos imaginarios para legitimar el poder regio fue una consecuencia lógica. En efecto, como bien lo señaló Marc Bloch, este fue uno de los elementos utilizados por las monarquías de Francia e Inglaterra para legitimar su autoridad. Para Jacques Revel (I2), las representaciones sobrenaturales ligadas a la existencia regia fueron tan importantes que pervivieron más allá de las discusiones teológicas y de los nuevos planteamientos políticos. Así, lo sagrado y lo religioso constituyeron un sistema articulado característico del poder real.

En este mismo sentido, Ernest Kantorowicz estudió la forma en la cual la teoría política utilizó las fórmulas y las metáforas de la teología para justificar y explicar el funcionamiento del poder. Así como en lo espiritual las sociedades debían estar orientadas a la salvación, en lo temporal la conservación del orden divino suponía una forma de organización social designada por Dios. En esta concepción jurídico-política, las sociedades se debían regir por una misma 
cabeza y unas mismas leyes a imagen y semejanza del cuerpo humano. Si bien esta concepción de raíz aristotélica era aplicable a cualquier comunidad corporativa — casa, vecindad, ciudad y reino-, el rey fue el portador de la potestas, que hacía referencia a su atribución de ser la cabeza que gobernaba las partes del cuerpo social y garantizaba el orden en el plano temporal.

La potestas estaba ligada directamente a la dignitas, que hacía referencia al carácter supratemporal del rey como garante del orden social. Es decir, que las atribuciones regias estaban asociadas al cargo y no a la persona que lo ejercía, por lo cual la potestad no moría con el rey, sino que se transfería a su heredero. De esta manera, la monarquía se proyectaba en el tiempo, más allá de los poderes específicos ejercidos por un monarca (Kantorowicz 205).

Como lo señala Kantorowicz, entre los siglos XiıI y xv se desarrolló en la Europa occidental una doctrina sobre la composición bipolar de los cuerpos de la realeza: uno natural, representado por el rey en ejercicio, y otro metafísico, representado en la monarquía como institución política. Esta doctrina se inspiraba en un precepto teológico, según el cual la iglesia era el corpus mysticum (207) que representaba a Cristo en la tierra y se distinguía del corpus naturale, individual y personal de Jesús de Nazaret. Mientras el primero era inmortal y trascendente, el segundo estaba limitado a la efímera existencia humana. La potestas y la dignitas fueron preceptos que legitimaron la autoridad del rey y la continuidad dinástica. Sin embargo, conviene resaltar que las concepciones orgánicas y trascendentes de la sociedad no implicaban en ningún caso unicidad, pero sí manifestaban la pretensión de universalidad a la que apelaron las monarquías para construir al mismo tiempo un poder compuesto y policéntrico, coherente y cohesionado ${ }^{4}$.

Esta estrecha unión entre el ámbito religioso y el político, común en la construcción política de las monarquías europeas, adquirió matices distintos según las experiencias históricas de cada territorio. En el caso hispánico, como bien lo ha anotado John Elliott (La España imperial), el mérito y éxito de los Reyes Católicos, Isabel y Fernando, no solo consistió en haber unificado el gobierno de las coronas de Castilla y Aragón, sino también en haber logrado imponer su autoridad por medio de la persuasión para atraer el apoyo de la aristocracia y de los poderes locales. 
La expulsión de los moros de la península ibérica y la seguida colonización americana fueron experiencias históricas que perfilaron la imagen de una monarquía providencial, líder de la cruzada santa en contra de los infieles. Según José Manuel Nieto Soria (Origenes de la monarquía), los ideales caballerescos y militares fueron la expresión más visible de dicha identidad. La guerra de Reconquista desempeńó un papel de primera importancia como experiencia colectiva de carácter épico, plena de valores y de objetivos heroicos. Como consecuencia, en la península ibérica las noblezas se estructuraron en conformidad con este ideal militar, el cual constituyó la fuente de ennoblecimiento y de honor más frecuente. Según lo indica Anthony Pagden (El imperialismo español), en el caso castellano se construyó la imagen real asociada al mérito bélico, siendo el rey el caballero noble en defensa de la religión.

Las bulas alejandrinas de I493, por medio de las cuales el papado romano concedió plenos derechos a Castilla para conquistar y evangelizar el Nuevo Mundo, institucionalizaron la imagen de la realeza castellana defensora de la fe. El título de monarquía católica selló un pacto indisoluble entre los imaginarios religiosos y las pretensiones políticas. Cerrar filas en torno a la cruzada santa trajo consigo enormes réditos políticos a la Corona castellana, que convirtió a la religión en su elemento aglutinante, lo cual ha sido estudiado por David Brading. Como sostiene Elliott en su texto Imperios del mundo atlántico, la hispánica era una monarquía compuesta, que supo "incorporar" y agregar diversos reinos, con fueros, prerrogativas y tradiciones disímiles, pero unificados en torno a la idea de una monarquía católica.

En este sentido, la metáfora básica de los reyes castellanos fue la del pater familias. Según apunta Xavier Gil, la monarquía se apoyaba en un pacto político, en el cual la Corona aseguraba la protección moral del reino a cambio de garantizar la continuidad de los ordenamientos jurídicos del territorio en el seno del conjunto superior (“Integrar" 7I). En efecto, este pacto político tenía su máxima expresión en los rituales de jura, mediante los cuales el príncipe juraba ante las cortes de cada reino. El rey, entonces, debía asegurar el buen regimiento ${ }^{5}$. Esta función implicaba distribuir justicia, entendida como la tenencia de lo que a cada uno correspondía, equilibrando el rigor y la clemencia, y mantener la paza partir de un particular cuidado. Es decir, que debía legislar mostrando atención alcanzado como consecuencia de la benéfica acción gubernativa del monarca virtuoso" (Nieto, Fundamentos 225). 
a la costumbre y el privilegio que en cada caso correspondían. En palabras del jurista y teólogo Rodrigo Sánchez de Arévalo (I405-I470):

Así la ciudad o reino, como sea de un cuerpo mixtico y proporcionado de ciertas partes y miembros, cuando algún miembro o parte de la ciudad excede a los otros conocidamente, según su proporción es causa de levantamientos y sediciones. (302)

Los súbditos, por su parte, en virtud de su fides cristiana, debían al rey castellano lealtad y obediencia. Desobedecer al rey en esta concepción implicaba contrariar el orden de Dios (Kantorowicz 196). Rodrigo Sánchez explicaba esta idea en las siguientes palabras:

[...] todo regimiento humano debe ser conforme a la monarquía divina, la cual es perfectísima y esta es regida por un Dios, rey y príncipe potentísimo regidor y gobernador de todas las cosas, del cual principado divino todos los otros humanos regimientos deben tomar ejemplo. (283)

Para X. Gil ("Integrar” 72), la tradición foral hizo posible que los súbditos de los territorios peninsulares trasladaran su lealtad a los reyes castellanos con aparente facilidad. Sin embargo, Elliott ("Rey y patria" 19) señala que para afianzar el poder monárquico fue necesario construir una representación sublime de la majestad, que permitiese la integración política.

Cuando Carlos V fue coronado, el mundo occidental vivía un periodo de hondas transformaciones: la expansión europea, la ampliación de los horizontes del humanismo, la acumulación progresiva de capital que desembocó en el mercantilismo, las transformaciones en la aprehensión cristiana del mundo y la formación de estructuras fiscales y militares propias de los Estados modernos. El Renacimiento aportó una imagen del rey Carlos V fuertemente nutrida de referentes e iconografías de la tradición romana clásica. Al respecto contamos con los estudios de Lisón Tolosana sobre la representación del rey a la manera de un imperator romano que, en carrozas y arcos triunfales, aseguraba el advenimiento de una gran monarquía católica y universal.

La monarquía hispánica, que tenía presencia en los dos orbes, debía iniciar el proceso de centralización política. Para ello, además de afianzar las fórmulas jurídicas y litúrgicas de legitimidad, era necesario reforzar ciertos aspectos simbólicos que facilitaran el ejercicio de la soberanía de acuerdo con las necesidades imperiales. José Manuel Nieto (Orígenes 44) resalta la aparición de una 
cierta conciencia simbólica, es decir, de una percepción de que la potestas y la dignitas del rey empezaban a requerir, cada vez más, las pautas de identificación exterior y signos que se asociaran automáticamente al ejercicio del poder regio.

Sin rituales de unción como los de los reyes de Francia o sin ceremonias de coronación como las de la casa real inglesa, la Corona hispánica tenía un séquito cortesano reducido y una etiqueta ceremonial limitada, que parecía no estar equilibrada con el enorme poder que el rey detentaba y quería mostrar. La tradición cortesana de la Corona de Castilla tuvo su punto de quiebre durante el reinado de Carlos V. El emperador, nacido y educado en la corte borgońona, dio los primeros pasos para equiparar el enorme poder político con la solemnidad requerida para un imperio. En 1520 reorganizó las categorías superiores de la nobleza y puso en marcha un proceso de diferenciación a escala protocolar, una especie de "culto a la diferencia", que preservaba el carácter sagrado del monarca (Jonge et al.).

Sin embargo, Carlos V seguía teniendo una corte itinerante, más cercana a la del rey medieval. Su hijo Felipe II fue el encargado de modificar esta situación estableciendo en I56I una corte fija, donde se unificó la residencia del rey con el centro administrativo de la monarquía. Las cortes surgieron como amplificaciones de la casa del rey (household). En ese ámbito, el monarca operaba como el jefe de familia y la casa real venía a constituir el órgano central de un Estado con carácter patrimonial (Martínez I5).

Madrid, el lugar escogido para la sedentarización del monarca, era un poblamiento sin importancia hasta ese entonces, en el centro de la península ibérica. Con la elección de aquel lugar, aparentemente neutro, Felipe II pudo apartarse espacialmente de las noblezas más poderosas y disminuir su excesiva influencia, para construir a partir de cero una capital del imperio con una corte planificada a su medida ${ }^{6}$.

Pero el establecimiento de una corte fija, además de tener una repercusión política fundamental, tuvo también un efecto cultural inherente, porque se convirtió en el canon cultural del Estado, el espacio por excelencia de producción y control de normas y valores con criterios selectivos. En otras palabras, la corte se convirtió no solo en el eje institucional de la monarquía, sino también en la capital de la imaginación política (Geertz I66).

6 Sobre la construcción de Madrid como capital de la monarquía gestada durante todo el siglo XVI, véase el importante estudio de Río Barredo, Madrid urbs regia. 
Para Noel, la adopción de la etiqueta borgoñona fue una parte fundamental de la construcción simbólica de la corte hispánica. En el año de 1548, en una misión que se le encargó al duque de Alba, mayordomo del príncipe Felipe, el borgoñón fue institucionalizado como el modelo ritual y de comportamiento de la corte hispánica. La etiqueta hacía referencia a un conjunto de códigos de comportamiento establecido para el servicio de la corte, fijado en un protocolo escrito. Este modelo tenía en cuenta todos los aspectos sobre la vida cotidiana de la familia real, incluyendo también regulaciones estrictas sobre el trato social entre los miembros de la corte, del mayor al menor rango (Río, "El ritual" 23). El ceremonial ejemplar, la jerarquía de modelos, la competición expresiva, la ritualidad extensiva y la dramatización pública se combinaron con una representación simbólica del rey que se presentaba ante sus cortesanos como una figura fija de la autoridad, un poder entre poderes, un signo entre signos, en términos de Checa (Carlos V).

Como lo demostró N. Elias, las etiquetas fueron una herramienta indispensable de control político para las monarquías europeas, porque a partir de ellas se sometió a la alta nobleza a un complejo juego de apariencias y despiadadas competencias por el prestigio simbólico. Además de ser un espacio de competencia por el estatus, los estudios sobre las cortes en los años recientes han llamado la atención sobre el rol de la corte real como espacio de construcción de la imagen pública del rey, instrumento de la política, fuente del patronazgo y centro productor de una cultura específica (Martínez). Recientes estudios sobre este aspecto han demostrado que las etiquetas regias, además de expresar físicamente las diferencias, naturalizando y focalizando al rey, permitieron imaginar el poder público ${ }^{7}$.

En el marco de una interpretación general del proceso civilizador de Elias, el ceremonial de corte fue el instrumento de aculturación que permitió transformar a los guerreros en cortesanos, para prevenir y sustituir la violencia. La tendencia a la pacificación sucedida desde finales de la Edad Media permite interpretar ceremonias, ritos y gestos como el medio pacífico y controlado, válido para contener las luchas por el poder.

La adopción del modelo borgoñón para la corte hispánica, rico en expresiones festivas de tradición medieval, fue una decisión controvertida que desató más de un resentimiento entre la nobleza castellana. El nuevo estilo era 
enormemente caro de mantener y tendía a aislar a los monarcas y a su familia. Según Noel, en 1558 las cortes castellanas afirmaban que los gastos derivados de la etiqueta eran "suficientes para conquistar y ocupar un reino" y recomendaban al rey volver a la acostumbrada organización doméstica castellana.

Como resultado, lo que terminó por imponerse fue un modelo híbrido, en el cual las tradiciones locales se fusionaron con las pautas borgoñonas y los monarcas sucesivos intensificaban o reblandecían ciertos aspectos. Tal y como lo advierte Noel, la etiqueta era una herramienta que los gobernantes modificaban para glorificarse y mantener el orden convencional. En la fachada lo que resultaba más importante era rodear el ejercicio del poder de historia y tradición (Noel I43).

\section{El cuerpo del rey barroco: un exemplum}

Según Martínez Millán, el establecimiento de la corte de la monarquía hispánica coincidió con una época de enormes cambios culturales: por un lado, se encontraban las tradiciones heredadas del mundo clásico y los imaginarios medievales, y, por otro, los primeros atisbos de la modernidad.

En este vértice entre la tradición y la modernidad se encontraba el Barroco, la gran empresa de propaganda del catolicismo creada en el Concilio de Trento. Río Barredo ("Felipe II y la configuración”) destaca al respecto que mientras los conflictos religiosos azotaban a Europa, la monarquía católica amplificó su mito. Ante la embestida reformista, la casa real española reforzó el papel de guardiana de la ortodoxia religiosa.

El Barroco calzó como anillo al dedo para el modelo de monarquía que Felipe II quería consolidar. El proyecto imperial hispánico era profundamente ambicioso. Un solo rey, una sola religión y una historia compartida fueron banderas políticas de la monarquía en sus territorios a uno y otro lado del Atlántico. El Barroco se presentaba, entonces, como una pedagogía moralizadora destinada a crear admiración y orientada a la persuasión por la vía del espectáculo. Se trataba de poner en marcha una estrategia cultural que procuraba construir la figura del rey y escenificar la estrecha unión entre el poder político y la misión salvadora del catolicismo (Checa, Felipe II). 
Con la sedentarización, la corte española desarrolló una especial conciencia sobre el cuerpo del rey como un territorio inaccesible, invisible, que fue definitiva para configurar los modelos de representación regia. Vinculado con las modalidades de espiritualidad generadas por la Contrarreforma, el cuerpo barroco no era solo la representación de lo exterior, sino también una condición interior. Se trató de un significativo avance de la disociación radical entre cuerpo y alma, que dominó la religiosidad medieval, según lo explica José Luis Bouza en su texto Religiosidad contrarreformista y cultura simbólica del Barroco.

En la nueva lectura, lo mental y lo espiritual se manifestaban físicamente, en particular a través de los movimientos. La fisionomía fue una teoría muy en boga según la cual el cuerpo y, más concretamente, el rostro eran un espejo de los vicios y las virtudes de las personas. Los gestos eran en este modelo un reflejo del alma que se debía vigilar y regular. Según Fernando Bouza (Palabra e imagen), el mundo se volvía un gran teatro exterior e interior para componer, a partir de todos los sentidos, la ubicuidad de los actos.

Felipe II, siguiendo este derrotero, elaboró una puesta en escena teatralizada de su propia imagen corporal que se caracterizaba por la inaccesibilidad. Para Elliott (España y su mundo 174), esta será la principal característica distintiva de la monarquía hispánica bajo el gobierno de los Austrias, con respecto a otras cortes de la Europa occidental.

En contraste con la exhibición del rey francés, el rey hispánico se "exhibía escondido". Esto implicaba cubrir su cuerpo de ropajes oscuros y de una sobria indumentaria. En aquellos tiempos, la gama cromática en telares y ropas era más que limitada. El acceso a los tintes era una característica de privilegio social en un mundo donde la monotonía del color era la norma. La realeza, por tanto, siempre estuvo asociada al monopolio del rojo y el azul, que eran los colores más escasos. De ahí que el poderío del rey francés o del inglés se reflejara en sus coloridas galas, exhibidas en un trono. Los Austrias, por el contrario, adoptaron un estilo austero y ascético que se extendió hacia la nobleza y luego a los circuitos de la administración estatal. Trajes absolutamente negros y cuellos rígidos —influencia del erasmismo flamenco- empezaron a usarse en toda la corte.

La tez pálida, las ropas de paño negro, una gestualidad mínima, la contención total de las emociones, una corporeidad domesticada y la rigidez de su figura completaban la exhibición de gravedad y majestad alimentada por la Contrarreforma.

Estas características del cuerpo del rey en la corte hacían parte de lo que para la sensibilidad barroca debía ser un cuerpo modélico, un exemplum. El 
principio partía de la idea de establecer un dominio sobre las pasiones, lo cual se manifestaba a través de una actitud corporal impasible. En el rostro y en los gestos, el rey debía exhibir dignidad, autoridad y carácter.

Fernando Bouza ha recogido algunos testimonios de los cortesanos de Felipe II: "La sonrisa del rey se cortaba como el filo de una espada" o "Que tiene ojos de gato que en el alma los enclava y deja un hombre temblando" "La majestad de Felipe II" 47-48) fueron unas de las muchas descripciones que circularon en la corte de dicho monarca, no solo para resaltar su corporeidad y gestualidad, sino también para hablar de las virtudes del buen gobernante.

Según anota Bouza, el mobiliario de palacio fue también útil para aumentar el efecto de invisibilidad durante las exhibiciones del rey en la corte. Cortinas oscuras, tribunillas ocultas, vidrieras y pasadizos escondidos hacían parte de los recursos decorativos que usó el rey para ser visible solo para unos pocos. "Que lo veía todo y no le veía nadie”, era la aterradora sensación palaciega.

La etiqueta de la Casa de Austria proponía al rey como un centro inaccesible: visible o imaginable, pero de muy difícil alcance (Río, Madrid 46). Sus apariciones públicas fueron cada vez más reducidas y mayor la ritualización cuando participaba. En las comidas públicas, por ejemplo, el monarca se sentaba en una mesa separada, aislado, pero a la vista de quienes acudían a presenciar el acto. Noel señala que, incluso en algunas funciones, el rey se ponía bajo un largo dosel de seda negra que lo ocultaba, pero que al mismo tiempo subrayaba su presencia.

Los propios teóricos del Barroco aconsejaban a los gobernantes el secreto, la dificultad de la comprensión, la oscuridad en función de lo difícil, como método para cautivar e imponer la fuerza de la majestad. Como resultado de este proceso, el triunfo del cuerpo invisible del rey sobre el cuerpo exhibido trajo consigo una resignificación de todos los elementos de legitimidad de la autoridad. Se reforzó la ritualidad para hacerla hiperreal, de manera que su materialidad solo podía ser imaginada, como se hacía con la de Cristo (Osorio, El rey en Lima 8). Río Barredo, en Madrid urbs regia, señala al respecto:

El cuerpo político, inmortal del rey podía caracterizarse precisamente por su invisibilidad y por la inmutabilidad [...] en el caso hispano, la invisibilidad como forma de abstracción de la personalidad política del monarca resulta especialmente convincente al considerarla en términos de la incertidumbre que provocaba entre sus súbditos y que, en último término, les llevaba a imaginarlo como un poder omnipresente. (47) 
Lo importante, políticamente, es que la construcción de esta imagen del rey ausente fortaleció el cuerpo místico de la monarquía. Esta idea del cuerpo invisible desligó de su presencia física el ejercicio de la soberanía real en los territorios de la monarquía, porque posibilitó la sustitución del cuerpo físico por la representación. En los diccionarios de la época - Covarrubias y Furetière- este concepto comprendía dos aspectos: el primero, en el sentido de lo visible, hacía referencia a mostrar, exhibir, figurar, "comparecer en persona y exhibir cosas". Y el segundo, como invocación, evocación, "sustitución de un objeto ausente a partir de un símbolo que toma su lugar” (Covarrubias; Furetière, cit. en Burke 17).

Las imágenes y los símbolos fueron fundamentales para crear el efecto de omnipresencia real. Para Pierre Chaunu (cit. en Gruzinski, La guerra), esta función de representar que se les atribuyó explica la necesidad física de la imagen, característica del mundo hispano.

Ante un público mayoritariamente iletrado, a medio camino entre la oralidad y la escritura, el cuerpo del rey barroco se construyó a través de imágenes, símbolos y puestas en escena. Durante los reinados de Felipe III, Felipe IV y Carlos II, la construcción de la imagen del rey sacrosanto y distante se elevó al rango de arte (Mínguez, La invención). En la producción de imágenes se desarrollaron ciertas metodologías visuales también llamadas técnicas de representación, entre las que destacaban la mnemotécnica y la emblemática. De manera que las imágenes eran lo que eran, pero "podían hablar", dar forma a una narratio, a través de un "texto oculto" cuyos códigos transmitían un conjunto de mensajes. Para Fernando Rodríguez de la Flor (Emblemas), la imagen del rey se codificó a partir de símbolos, jeroglíficos y emblemas.

Todos estos elementos convergieron en cuadros ceremoniales, a través de los cuales el rey se hacía presente en todos sus territorios ${ }^{8}$. Este fenómeno, denominado por José Antonio Maravall teatralización del poder, o el efímero de Estado en términos de Fernando Rodríguez de la Flor, hace referencia al retroceso de lo real a favor de lo ilusorio, de lo reconstruido, de lo mediato y lo espectacular'. Estas denominaciones relacionan directamente las ceremonias públicas y

8 Sobre este aspecto ver el proyecto “Triunfos barrocos”, dirigido por Víctor Mínguez, que compiló en cuatro volúmenes un grupo significativo de imágenes de arte festivo en la monarquía hispánica.

9 Una interesantísima relectura del texto de 1975 La cultura del Barroco, de José Antonio Maravall, es la obra de Fernando Rodríguez de la Flor, Barroco. Representación e ideología en el mundo hispánico, publicado en el 2002. 
la imagen del rey con la producción artística, para expresar la simbiosis entre lo visual, lo literario y lo auditivo, como lo ha estudiado Canadine.

Elliott ("Poder y propaganda") enfatiza la efectividad de esta estrategia seguida por la monarquía hispánica. Los reyes españoles evitaban los rituales de coronación, no tenían poderes taumatúrgicos ni se exhibían con corona o con cetro. No obstante, gobernaron tierras diversas y la majestuosidad de su imagen fue una percepción compartida entre sus coetáneos. El éxito de la monarquía estaba ligado a la creación de una comunidad de intereses que mantenían unido el núcleo a sus partes. En este núcleo se encontraba el rey, físicamente invisible pero omnipresente en sus reinos a partir de su representación.

\section{Los dos cuerpos del rey en la corte hispánica}

La perpetuidad de la monarquía era una de las condiciones necesarias para la estabilidad del reino. En los territorios bajo su dominio, los ciclos de vida del rey eran una metáfora de la trascendencia y perpetuidad del orden social. Las exequias celebraban la mortalidad del cuerpo natural del rey, mientras que la jura escenificaba el traspaso del poder místico y, al mismo tiempo, la continuidad de la estabilidad del orden social. Esto significaba que el cuerpo inmaterial, que se superponía al material, no podía morir jamás, para que la comunidad pudiera existir eternamente (Vigarello 376).

De acuerdo con esta misma liturgia, el nacimiento de un nuevo miembro de la familia real, especialmente si se trataba de un heredero, se festejaban porque garantizaban la continuidad de la línea sucesoria. En una época marcada por altísimas tasas de mortalidad infantil, las familias reales debían asegurar la mayor cantidad de vástagos posibles para garantizar la buena salud de la dinastía. Las bodas reales, por su parte, eran una eficaz estrategia para acrecentar el poder. Además de crear un marco legal para la reproducción de la dinastía, las nupcias eran parte de la estrategia política y servían para construir y consolidar las relaciones diplomáticas del imperio ${ }^{\mathrm{IO}}$. Asimismo, la transferencia del

Io De los matrimonios dinásticos se ocupa el libro coordinado por Palos y Sánchez. 
poder ha sido uno de los aspectos rituales y ceremoniales más importantes del Antiguo Régimen ${ }^{\text {II }}$. Como lo apunta Catherine Lafages, permitía consagrar a los reyes como figuras supratemporales.

Este largo trance ceremonial, que iniciaba con la muerte del rey y terminaba con la proclamación de su heredero, escenificaba a la perfección la metáfora de los dos cuerpos del rey. Las exequias reales eran muerte, silencio, oscuridad. Transcurrido un tiempo de duelo, llegaban el júbilo, la música, el color. La liturgia de la monarquía se construyó a imagen y semejanza de la Cuaresma y la resurrección de Cristo. Este enfrentamiento tensional entre el dolor y la alegría, que tanto apasionaba al Barroco, daba un sentido monumental a estas ceremonias.

La visión de los dos cuerpos del rey y su puesta en escena surtió efectos sobre las prácticas estatales, pues se impuso una perspectiva física del poder y de la ley. Las fronteras del espacio público y privado se encontraban pues entremezcladas, inevitablemente, con el cuerpo del rey.

Para José Manuel Nieto (Fundamentos ideológicos) y Javier Varela, la muerte regia fue especialmente significativa para la monarquía católica. Habitualmente, la ceremonia fúnebre comenzaba con el rey o la reina aún agonizantes. Como atestiguan algunos escritos piadosos, para la sensibilidad barroca era preferible una larga agonía que una muerte repentina. Las personas reales hacían gala de su capacidad para predecir su propia muerte como un símbolo de gracia divina ${ }^{12}$.

I I Varios estudios han tratado este aspecto. Las ceremonias de la Castilla Trastámara han sido analizadas por José Manuel Nieto Soria, mientras que Bonifacio Palacios Martín ha abordado los rituales de coronación en el reino de Aragón y Ralph Giesey se ha aproximado a los funerales regios en la Francia del Renacimiento. Para la época moderna contamos con los estudios de Edward Muir sobre las ceremonias venecianas; María Pilar Monteagudo Robledo para las ceremonias reales en Valencia; María Ángeles Pérez Samper y Alfredo Chamorro para el caso de Barcelona; y Roberto J. López ha estudiado las ceremonias en Galicia. Todos estos trabajos han llamado la atención sobre la importancia de las exequias reales y de las juras para escenificar la distinción entre el cuerpo natural del rey que muere y el cuerpo místico de la monarquía, que resucita. También han puesto de relieve que estos rituales eran espacios de transmisión de imágenes e imaginarios de la naturaleza regia, útiles para legitimar y afianzar su poder. Sobre ceremonias reales en los dominios americanos, véanse el importante estudio de Alejandra Osorio sobre Lima, los estudios de Jaime Valenzuela para el caso de Chile, los de Juan Chiva para México, Eugenia Bridikhina para Charcas y Verónica Salazar para el Nuevo Reino de Granada, entre otros. También el reciente texto editado en el 2015 por Checa y Fernández-González.

I2 Es el caso de Carlos V y Felipe II, quienes interpretaron un evento astronómico - el paso de un cometa- como un anuncio de su muerte; mientras que María Luisa de Orléans tomó la caída de un caballo como un anuncio de su deceso (Varela 63). 
En el terreno político, un rey aquejado por una larga enfermedad desestimaba cualquier sospecha de posibles conspiraciones. Pero quizás lo más atractivo de una larga enfermedad era que permitía al moribundo redactar su testamento, inventariar sus bienes y posesiones más queridas, a la vez que le daba la oportunidad de intervenir en la preparación de su propio funeral.

Aunque el lecho del enfermo se encontraba restringido a sus más cercanos, las noticias de su enfermedad circulaban en la corte con especial detalle. Para el rey, como para todo buen cristiano, el camino a la espiritualización del cuerpo dependía en gran medida de la experiencia y aceptación de la enfermedad. Esta era la articulación entre la vida y la muerte, la posibilidad del encuentro en comunión con Dios. El cuerpo enfermo, en camino hacia la muerte, debía "resignarse" al dolor para encontrar la ruta de la perfección.

Según Ralph Giesey, la agonía pública del rey español es el síntoma que evidencia una relación distinta con la muerte y la enfermedad. En el caso de los reyes franceses, por ejemplo, la agonía era mantenida en secreto para crear distancia con sus súbditos. En la Corona castellana, en contraste, la enfermedad del rey servía para resaltar la naturaleza humana del monarca y su cercanía con el ámbito sagrado. La enfermedad era una buena ocasión para que los miembros de la familia real se mostraran como cristianos ejemplares ante sus cortesanos, reafirmando así el mito de una monarquía tocada por Dios.

"Menos que Dios y más que los hombres", era la idea que buscaba reafirmarse. La agonía acercaba al rey a sus súbditos, pero la muerte lo distanciaba, pues las personas reales no estaban expuestas como cualquier cristiano a pasar por el purgatorio y, mucho menos, a habitar en el infierno. Por el contrario, su tránsito a la gloria eterna estaba asegurado (Varela I25). Las cédulas reales, por medio de las cuales se comunicaba la noticia del fallecimiento del rey, ahondan en este aspecto ${ }^{13}$.

Ahora bien, una vez el rey moría, su cuerpo se sometía a diversos tratamientos. Aunque con el tiempo los procedimientos funerarios se estandarizaron, es visible la influencia de tradiciones culturales diversas y la preocupación que suscitó el

I3 Un ejemplo, entre muchos otros en este sentido, podemos verlo en la cédula real mediante la cual Felipe IV informaba en I62 I que a su padre le había sobrevenido una grave enfermedad y, luego de la impartición de los sacramentos, "ha sido Nuestro Señor servido de llevarle, mostrando en la muerte como en la vida su ejemplar cristiandad y como quiera que mediante esto se puede tener piadosamente por cierto que Nuestro Señor le tenga en su santa gloria" (AHE, SG, caja 3, exp. 4, 1622). 
manejo del cuerpo natural del rey. Como lo indica Varela, la tradición castellana y aragonesa del embalsamamiento incluía una compleja intervención del cadáver para remover las vísceras, que eran a su vez preservadas como cosa de grandísima importancia. El corazón del rey, por ejemplo, tenía un alto valor simbólico y era preservado. A esta tradición se sumó también una curiosidad médica y política, pues descubrir las causas de la muerte del rey resultaba ser relevante. Como resultado, existía una profunda familiaridad con el cadáver del rey, expresada en narraciones pormenorizadas de las disecciones. Sin embargo, esta práctica convivía con otra sensibilidad corporal de corte erasmista, según la cual el cuerpo era una prisión del alma y, como tal, cualquier esfuerzo de intervención y preservación era censurable.

Finalizado este procedimiento, el cuerpo del rey era vestido con los hábitos de una orden religiosa, escogida previamente. El mensaje que este atuendo transmitía a los cortesanos tenía mucho que ver con la desposesión material con la que todo cristiano ejemplar debía enfrentar la muerte. A partir de Felipe IV, la vestimenta del rey se cambió por sus galas y condecoraciones oficiales, en tanto que el hábito religioso se mantuvo para las reinas y los infantes. En todos los casos, luego de ser vestido, el cuerpo se mantenía en las habitaciones reales por un día completo. Las campanas y las misas anunciaban la noticia al exterior, mientras que dentro de palacio el cuerpo de guardia se trasladaba al cuarto del sucesor para asistir a la lectura del testamento en cámara regia. A partir de ese momento, el príncipe heredero debía permanecer oculto hasta tanto su predecesor no desapareciera de la escena.

Luego venía la etapa más pública del funeral regio: el traslado y la velación del cuerpo del rey, en la que podían participar todos los miembros de la corte y algunos invitados. El canon institucional determinaba que las exequias en palacio duraran dos jornadas. En la primera, las vísperas, maitines y laudes y durante la segunda, tres misas solemnes: la de Nuestra Señora, la del Espíritu Santo y la de réquiem, celebradas todas en la capilla real. En esta última se pronunciaba la oración fúnebre que resumía el acto: invitación, lamento, exposición de las virtudes del difunto, feliz muerte y elevación al reino de los justos.

La oración fúnebre, estudiada por Eliseo Serrano, fue la liturgia característica de las exequias reales. Se trataba de un género proveniente de la Antigüedad clásica, reinventado para los propósitos ideológicos del Barroco. Su primer antecedente fueron las deploratio funebris, concebidas como una exaltación solemne a un muerto ilustre. La Iglesia católica adoptó este género con mucho éxito; en el siglo IV aparecieron las primeras oraciones fúnebres que forman parte de la 
tradición patrística. En la Edad Media, la escolástica y la retórica enriquecieron la oración y la convirtieron en sermón. El elogio del difunto sirvió más que todo en este nuevo escenario para la identificación cristiana del oyente, y buscaba valorizar los bienes eternos y el menosprecio de los terrestres.

Este género, implementado dentro de los programas ceremoniales castellanos por Carlos V, adquirió mayor importancia en el reinado de Felipe II, cuando se publicó para su lectura en la corte, vivió su época de oro entre los siglos XVI y Xvir. Fueron numerosas las obras que trataban sobre el "arte de predicar". La oración fúnebre cumplía funciones didácticas y doctrinales. Se trataba de un sermón que predicaba la universalidad de la muerte, la miseria del hombre pecador sin Dios, pero que al mismo tiempo anunciaba la esperanza de la redención. Este último componente abría paso a la laudatio funebris, en la cual se exaltaban las virtudes del difunto, quien era presentado como modelo a los demás mortales. Dos aspectos aparentemente contradictorios, pero en realidad complementarios. Por una parte, se humanizaba al rey a partir de su mortalidad, pero a la vez se lo divinizaba señalando las virtudes que lo situaban tan cerca de Dios.

Para Jaime Valenzuela, la oratoria barroca desarrolló la idea de que el recién fallecido, así como todos sus antecesores, había sido persona virtuosa y merecedora de la gloria eterna. Como una extensión lógica de la dignitas, la familia y los descendientes regios eran poseedores de la misma gracia. Las personas reales morían, su cuerpo estaba sujeto a los avatares del tiempo, pero su virtud cristiana era capaz de redimir el inexorable destino de la muerte. La persistencia de este mensaje permite pensar que la muerte regia no era un hecho político limitado a la transferencia del poder, sino que asumía una importante dimensión catequística.

En los sermones fúnebres regios se evocaban tres temas principales. En primer lugar, los orígenes del muerto, remarcando el legado dinástico. En segundo lugar, se elogiaba la vida ejemplar del difunto con sus actuaciones virtuosas. Finalmente, se exaltaba la ejemplaridad de su tránsito a la muerte. Esta exaltación se situaba en un contexto de referencias mitológicas, de orden bíblico — Antiguo o Nuevo Testamento—, clásico — mundo griego o romanoo cristiano - formas de divinización, sacralización o santificación- (Nieto, Orígenes 3I). Una vez finalizaba el acto litúrgico, se realizaba una procesión compuesta originalmente por la familia real y su corte.

El gran proyecto de Felipe II de establecer una corte fija incluía un panteón único de la realeza hispánica. La figura del palacio conventual —residencia, capilla y cripta - reivindicaba, por una parte, la estrecha relación entre poder 
político y poder eclesiástico y, por otra, reafirmaba en términos simbólicos la idea del cuerpo físico y el cuerpo místico del rey, proclamando la inmortalidad y el carácter divino de la realeza. En asuntos más prácticos, la coincidencia entre la residencia real y el panteón en El Escorial debía evitar los largos desplazamientos del cortejo fúnebre y, en efecto, se planteó un protocolo ceremonial in situ en el que la agonía, la muerte y las exequias tuvieran lugar con un mínimo desplazamiento. Esta reducida movilidad creó un nuevo perfil funerario, en el que se restó protagonismo al cuerpo físico del rey y se privilegió la centralidad del símbolo funerario (Allo y Llorente).

Mientras los funerales se llevaban a cabo, la corte debía demostrar su dolor por la pérdida del rey, sin que ello significara excederse en las emociones. Coincidiendo con la domesticación de las emociones, explicada por Elias, durante el siglo xvi y una vez más por influencia del erasmismo, las dramáticas manifestaciones de dolor empezaron a ser reprobadas. Las constituciones sinodales hicieron también lo propio, acogiéndose al principio según el cual la muerte del rey era el nacimiento de una vida gloriosa. Voces, gritos y llantos empezaron a remplazarse por gestos y ademanes ritualizados que terminaron por imponerse conforme avanzó el siglo Xviı, como lo señala Varela.

El propósito de las exequias reales era narrar la vida, la muerte y los logros del monarca; en ellas el cuerpo natural del rey era el protagonista. Por el contrario, los rituales de acceso al trono tenían como protagonista al cuerpo místico de la monarquía. Como consecuencia, la centralidad del símbolo fue mayor en este último caso.

La entronización se considera el ritual más declarativo sobre el origen del poder, las relaciones entre gobernantes y gobernados y la constitución política de las monarquías. La sucesión escenificaba la trasmisión de un rey a otro de los valores trascendentes e inmortales del cuerpo místico. Como ritual, representaba una prueba fundamental de la inalterabilidad del orden social, pues al margen de la mortalidad del cuerpo natural, el cuerpo místico se reencarnaba en el sucesor.

El ritual de sucesión de la monarquía francesa se realizaba en la catedral de Reims. El cuerpo del rey se ungía con crisma sagrado de la Santa Ampolla, la botella que, según se decía, había traído una paloma del cielo para ungir a Clodoveo. El obispo colocaba en la mano derecha el cetro y en la cabeza del nuevo rey, la corona de Carlomagno.

En la Corona castellana, sin embargo, este era un ritual inexistente, porque no eran la coronación o la unción las que transmitían el poder del rey, sino la muerte de su predecesor, el derecho hereditario. La sucesión era en su origen 
un pacto legal que unía al rey con un pueblo representado en las cortes. El rey estaba obligado a aplicar justicia y proteger las costumbres del reino, combatir a los moriscos y recuperar los territorios visigodos. La ceremonia de armarse caballero tenía entonces especial significado, y era el mismo rey quien se autoimponía la espada (Monteagudo, La monarquía ideal).

En el territorio peninsular existían diversas tradiciones en cuanto a las insignias que se utilizaban en el ritual de sucesión. Por lo general, los reyes eran conscientes de que en sus circunstancias era mejor reforzar los lazos con las costumbres locales que entrar en conflicto con ellas, y de ahí que las tradiciones locales hayan sido en general respetadas.

El carácter localista de las sucesiones en la monarquía hispánica determinó la existencia o la ausencia de algunas pautas y muchas variables en los protocolos de celebración. En Castilla, por ejemplo, las insignias características eran las espuelas y el pendón, alusivas al autonombramiento de caballero que el monarca debía realizar. En Aragón, por su parte, el pomo, el orbe y la diadema de los condes de Barcelona eran lo típico. En Navarra la costumbre era el alzamiento del rey sobre el escudo. Aunque estas tradiciones se mantuvieron, el uso del pendón real fue en general el símbolo que se impuso para las juras reales (Río, "Felipe II y la configuración").

Según Nieto Soria, las pretensiones autoritarias de la monarquía castellana se hicieron visibles en los ceremoniales de jura, pues, a partir de sus campañas militares, se enfatizó su sacralidad inmanente, de espaldas al ámbito eclesiástico. Generalmente, el ceremonial de jura iniciaba con la conocida fórmula "iel rey ha muerto, viva el rey!”. Una vez declarada la muerte del rey, los consejeros reales comunicaban la designación al sucesor. En un momento extremadamente simbólico, se le cambiaba de ropas, con lo cual abandonaba su rol de príncipe para convertirse en el nuevo rey. Esta escena evocaba la toma de hábitos de los votos sacerdotales. Con la ordinatio regis, el nuevo rey ponía su cuerpo a disposición de la comunidad política que representaba y renunciaba a su existencia mundana (Nieto, Orígenes).

Para evitar confusiones, después del funeral de Carlos V los protocolos ceremoniales establecieron que el nuevo rey debía permanecer oculto durante las exequias de su antecesor, y una vez el cuerpo físico del monarca muerto desaparecía de la escena, su sucesor podía entrar en ella. El aislamiento protocolar, la expectación del público y su compostura solemne, no espontánea y grave, anunciaban el paso de lo humano a lo trascendente. El príncipe era en adelante el heredero de la dignitas que atribuía un carácter metafísico, trascendente e 
imperecedero a la realeza. La perpetuidad del cuerpo místico tenía lugar con independencia del cuerpo natural, mortal e intrascendente del monarca.

Originalmente, en la monarquía católica la ceremonia de jura fue un acto de reconocimiento netamente político, mediante el cual el sucesor debía llevar a cabo una extensa gira por todas las provincias. Recordemos que, tal como lo ha indicado Elliott ("Rey y patria"), la hispánica era una monarquía compuesta, formada por varios reinos que se regían por normas, acuerdos y privilegios resultado del derecho consuetudinario.

Para garantizar el éxito de la sucesión, en los días siguientes a la muerte del rey debía emprenderse una ofensiva diplomática de gran alcance para que los distintos reinos aseguraran los derechos del nuevo rey y le prometieran obediencia, en un juramento recíproco en el que este, a cambio, juraba respetar los fueros y privilegios del reino. La entrada real era la forma ceremonial que permitía al rey pactar con las cortes y realizar la jura, en algunas ocasiones, en la plaza pública de la capital de cada reino (Pérez, "La presencia del rey").

Varias veces, las exequias y la ceremonia de jura se yuxtaponían en un corto espacio temporal, de manera que los protocolos imponían la anulación del luto mientras transcurría la jura. Así, también, se prohibían las expresiones de tristeza durante la jubilosa celebración.

La celebración iniciaba con el Te Deum laudamus. Inventada en el siglo v, se trataba de una oración alegórica cantada en latín que alababa la gloria eterna de Dios y el triunfo de la Santísima Trinidad en la tierra. Originalmente, estaba destinada a celebrar un acontecimiento eclesiástico — canonizaciones, ordenaciones sacerdotales y elecciones del nuevo papa-. Sin embargo, la clara referencia al poder de Dios le dio una connotación política que la monarquía católica supo aprovechar, aplicándola como una celebración de poder terrenal. El principio al que apelaba era el mismo antes descrito: el triunfo ritual de la fe apoyaba simbólicamente el triunfo del poder político (Valenzuela 176). Se convirtió así en un himno litúrgico destinado, en particular, a solemnidades triunfales en las que participaba el rey.

A continuación se establecía la jerarquía del reino: el alto clero — arzobispos, obispos y abades —, la nobleza — duques, condes y marqueses —, la alta burocracia de la monarquía, los procuradores de las cortes y otros asistentes. Un delegado de las cortes procedía entonces a declarar el acto de reconocimiento y a indicar las condiciones especiales, cuando las había. Luego venía el juramento público del rey. Ahora bien, a medida que el absolutismo monárquico se fortaleció, las ceremonias de sucesión empezaron a estandarizarse. La relación es 
muy simple: a medida que el rey acumulaba poder, la ceremonia de jura empezó a perder el carácter contractual que le era tan característico. La centralización del ritual de sucesión fue uno de los signos que anunciaron la llegada del absolutismo monárquico ${ }^{\mathrm{I}}$.

Como lo indica María Pilar Monteagudo Robledo (La monarquía ideal), la etiqueta y los protocolos de celebración desempeñaron en este sentido un rol crucial, pues la pretensión de hacer más homogéneo el ceremonial sucesorio de los distintos territorios aumentó el carácter dinástico del juramento y le restó valor al jurisdiccional.

Si antes el juramento se hacía ante las cortes, en el nuevo modelo el heredero empezó a jurar sobre los evangelios y ante la cruz. Las nociones del rey vicario de Dios, o la del cuerpo místico, respaldaron sin duda un modelo ceremonial en el cual el rey era responsable de su cumplimiento ante Dios y no ante las cortes. De manera que se cambió el juramento de una relación horizontal entre rey y reino por otra vertical del monarca con Dios.

En el plano legal, los Borbones se apoyaban en la noción de rex dei gratia para dotar la figura del rey de legitimación. De la misma manera en que el papa era el designado por gracia de Dios para regir los destinos espirituales de sus súbditos, el rey de la monarquía católica era el vicario de Dios en los asuntos terrenales. Como consecuencia, todo privilegio, derecho o participación se transformaba en una donación del rey, que provenía a su vez de la gracia divina. El rey disponía de un poder supremo sobre el territorio porque Dios le había confiado el reino en su totalidad, incluyendo a laicos y eclesiásticos, lo cual implicó su intervención en aspectos doctrinales.

Esta concepción entrañaba el viraje de una monarquía pactista a una absolutista, por derecho divino. Para Monteagudo Robledo (La monarquía ideal), mientras que las gestiones políticas para reconocer al sucesor como nuevo rey empezaron a ser consideradas en el ceremonial un asunto de segundo orden - parecía poco probable que las cortes se opusieran a los designios de Dios-, al mismo tiempo, la solemnidad de los actos fue en aumento.

En este sentido, la nueva dinastía aseguró la continuidad de las etiquetas cortesanas borgoñonas características de los Austrias españoles. Pérez Samper ("Imagen de la monarquía") ha señalado que la nueva dinastía buscó su

I 4 Para Río Barredo ("Felipe II y la configuración”), la jura de Felipe II en Aragón en el año de I542 es quizás un importante punto de quiebre, porque el nuevo monarca juró simultáneamente sobre los fueros y sobre la Biblia (682). 
conservación presentándose como heredera de una larga tradición monárquica. Simultáneamente, se mostraba como promotora del cambio, de la modernización y del progreso. Esta postura la comparte Roberto J. López, quien resalta el interés de los Borbones por consolidar la idea de continuidad de la monarquía hispánica, agregando algunos elementos novedosos que no restaban sino que, por el contrario, buscaban sumar. La monarquía española proseguía su historia de siglos, pero renacía de sus cenizas como una nueva ave Fénix, mostrando un rostro remozado, bello y atractivo. Esta perspectiva ha sido discutida recientemente por Manuel Rivero Rodríguez, para quien el modelo cortesano construido por la monarquía hispánica desde el siglo xvi experimentó su decadencia a partir de la segunda mitad del siglo XviII. Tal decadencia, según este autor, habría sido especialmente marcada en los virreinatos americanos. Los dramáticos efectos políticos se materializarían en los albores del siglo xIx.

\section{Consideraciones finales}

Los que estudiamos el mundo colonial americano con frecuencia dejamos de lado que la monarquía hispánica incluía también los territorios de Portugal, Milán, Nápoles, Sicilia, los Países Bajos y las Indias Orientales. Un vasto territorio, culturalmente diverso, donde la ausencia corporal del rey contrastó con élites locales muy activas políticamente. Los desafíos para el ejercicio del poder fueron muchos y las formas coercitivas no son suficientes para comprender su aparente estabilidad. La monarquía hispánica fue en este sentido una estructura de poder moderna, que utilizó el soft power para conseguir, a través de un sofisticado arsenal de recursos culturales y simbólicos, la sumisión de sus súbditos, reemplazando en muchos casos el cuerpo físico del rey por una puesta en escena. En efecto, gracias a ello, las autoridades regias pudieron crear la percepción de consenso, pese a las enormes tensiones existentes entre los reinos. Por esta razón, el cuerpo del rey, como cuerpo político de la monarquía, permite rastrear los esfuerzos, éxitos y fracasos en la construcción del poder, la legitimidad y la percepción de totalidad dentro del primer imperio transatlántico. 


\title{
$\infty$ \\ B I B L I O G R A F
}

\section{F U E N T ES PRIMARIA S}

\author{
A. Archivos \\ Archivo Histórico del Ecuador (AHE). \\ Serie Gobierno $(S G) 3$.
}

\section{B. Impresos}

Covarrubias, Sebastián. Diccionario de autoridades. Madrid, i6ri. Web.

Furetière, Antoine. Dictionnaire universel, 3 vols. La Haya y Róterdam: Arnoud et Reinier Leers, I674.

Sánchez de Arévalo, Rodrigo. Suma de la politica. Prosistas castellanos del siglo XV, edición y estudio preliminar de Mario Penna. Colección Biblioteca de Autores Españoles, t. cxvi. Madrid: Atlas, I959, pp. 252-309.

\section{F UENTES SECUNDARIAS}

Allo Manero, María Adelaida y Juan Francisco Esteban Llorente. "El estudio de las exequias reales de la monarquía hispana: siglos XVI, XVII, xviII. Antigrama, n. ${ }^{\circ}$ I9, 2004, pp. 39-94.

Bloch, Marc. Los reyes taumaturgos. Ciudad de México: Fondo de Cultura Económica, I983.

Bouza, Fernando. "La majestad de Felipe II. La construcción del mito real”. La corte de Felipe II, dirigido por J. Martínez Millán. Madrid: Alianza Editorial, r999, pp. 4748.

---. Palabra e imagen en la corte. Cultura oral y visual de la nobleza en el Siglo de Oro. Madrid: Abada Editores, 2003.

---. Religiosidad contrarreformista y cultura simbólica del Barroco. Madrid: Consejo Superior de Investigaciones Científicas, I990.

Brading, David. Orbe indiano. De la monarquía católica a la república criolla. 1492-1867. Ciudad de México: Fondo de Cultura Económica, 1998.

Braun, Harald y Jesús Pérez Magallón. The Transatlantic Hispanic Baroque. Complex Identities in the Atlantic World. Farnham: Ashgate Press, 2014. 
Bridikhina, Eugenia. Teatrum mundi. Entramados del poder en Charcas colonial. Lima: Instituto Francés de Estudios Andinos, 2007.

Burke, Peter. La fabricación de Luis XIV. Madrid: Editorial Nerea, I995.

Cannadine, David y Simon Prince. Rituals of Royalty. Power and Ceremonial in Traditional Societies. Cambridge: Cambridge University Press, I987.

Cardim Pedro, Tamar Herzog, José Javier Ruiz Ibáñez y Gaetano Sabatini. Polycentric Monarchies. How Did Early Modern Spain and Portugal Achieve and Maintain a Global Hegemony? Eastbourne, Reino Unido: Sussex Academic Press, 20 I2.

Cerdan, Francis. "La oración fúnebre del Siglo de Oro. Entre sermón evangélico y panegírico sobre el fondo de teatro”. Criticón, n. ${ }^{\circ}$ 30, 1985, pp. 78-102.

Chamorro Esteban, Alfredo. "Ceremonial monárquico y rituales cívicos. Las visitas reales en Barcelona desde el siglo Xv-Xvir". Tesis doctoral, Universidad de Barcelona, 20I3.

Chaunu, Pierre. L'Espagne de Charles Quint. París: Sedes, I973.

Checa, Fernando. Carlos Vy la imagen del héroe en el Renacimiento. Madrid: Taurus, I987.

---. Felipe II: mecenas de las artes. Madrid: Editorial Nerea, I992.

Checa, Fernando y Laura Fernández-González. Festival Culture in the World of Spanish Habsburgs. Nueva York: Routledge, 2015.

Chiva, Juan. El triunfo del virrey. Glorias novohispanas: origen, apogeo y ocaso de la entrada virreinal. Castelló: Editorial Universidad Jaume I, 2 or2.

Elias, Norbert. La sociedad cortesana. Ciudad de México: Fondo de Cultura Económica, I982.

Elliott, John. Emblemas: lecturas de la imagen simbólica. Madrid: Alianza Editorial, I995.

---. La España imperial. I569-I7I9. Madrid: Vicens-Vives, I974.

---. España y su mundo. I50o-I700. Madrid: Alianza Editorial, I990.

---. Imperios del mundo atlántico. España y Gran Bretaña en América (1492-I830). Madrid: Editorial Taurus, 2006.

---. "Poder y propaganda en la España de Felipe IV”. Homenaje a José Antonio Maravall, coordinado por Rodríguez et al., vol. 2. Madrid: Centro de Investigaciones Sociológicas, 1985, pp. 15-42.

---. “Rey y patria en el mundo hispánico”. El Imperio sublevado, editado por Manuel Chust y Víctor Mínguez. Madrid: Consejo Superior de Investigaciones Científicas, 2004, pp. I7-36. 
Geertz, Clifford. "Cetros, reyes y carisma: una reflexión sobre el simbolismo del poder". Conocimiento local. Ensayos sobre la interpretación de las culturas. Barcelona: Paidós Ibérica, 1994, pp. I47-I71.

Giesey, Ralph. "Models of Rulership in French Royal Ceremonial". Rites of Power. Symbolism, Ritual and Politics since the Middle Age, editado por Sean Wilentz. Filadelfia: University of Pennsylvania Press, I999, pp. 4I-64.

Gil Puyol, Xavier. “Integrar un mundo: Dinámicas de agregación y de cohesión en la monarquía de España”. Las Indias Occidentales: procesos de incorporación territorial a las monarquías ibéricas (siglos XVI a XVIII), editado por Óscar Mazín y José Javier Ruiz Ibáñez. Ciudad de México: El Colegio de México, Red Columnaria, 20I2, pp. 69-108.

---. "Una cultura cortesana provincial: patria, comunicación y lenguaje en la monarquía hispánica de los Austrias”. Monarquía, imperio y pueblos en la España moderna, coordinado por Antonio Mestre et al., vol. I. Alicante: Universidad de Alicante, I997, pp. 225-258.

---. "Un rey, una fe, muchas naciones. Patria y nación en la España de los siglos XVIXVII". La monarquía de las naciones: patria, nación y naturaleza en la monarquía de España, coordinado por Bernardo José García García y Antonio Álvarez-Ossorio Alvariño. Madrid: Fundación Carlos de Amberes, 2004, pp. 39-76.

Gruzinski, Serge. Las cuatro partes del mundo. Ciudad de México: Fondo de Cultura Económica, 2010.

---. La guerra de las imágenes. De Cristóbal Colón a Blade Runner. Ciudad de México: Fondo de Cultura Económica, I994.

Herrero Sánchez, Manuel, editor. Repúblicas y republicanismo en la Europa moderna. Siglos XVI-XVIII. Ciudad de México: Fondo de Cultura Económica, 2017.

Jonge, Krista de, Bernardo J. García et al. El legado de Borgoña. Fiesta y ceremonia cortesana en la Europa de los Austrias (I454-I648). Madrid: Editorial Marcial Pons, Fundación Carlos de Amberes, 2010.

Kantorowicz, Ernest. Los dos cuerpos del rey. Un estudio de teología politica medieval. Madrid: Alianza Editorial, I985.

Lafages, Catherine. "Realeza y ritual en la Edad Media: ritos de coronación y ritos funerarios en Francia”. Honor y gracia, editado por Julián Pitt-Rivers y J. G. Peristiany. Madrid: Alianza Universidad, I993, pp. 38-76

Le Goff, Jacques. "Prefacio". Los reyes taumaturgos. Marc Bloch. Ciudad de México: Fondo de Cultura Económica, i988. 
Lisón Tolosana, Carmelo. La imagen del rey: monarquí, realeza y poder ritual en la Casa de Austria. Madrid: Real Academia de Ciencias Morales y Políticas / Editorial Espasa, I99I.

López, Roberto J. Ceremonia y poder a finales del Antiguo Régimen. Galicia, I7ooI833. Santiago de Compostela: Servicio de Publicaciones de la Universidad de Santiago, I995.

Maravall, José Antonio. La cultura del Barroco. Análisis de una estructura histórica. Barcelona: Ariel, I975.

Marin, Louis. Le portrait du roi. París: Éditions de Minuit, I98I.

Martínez Millán, José. “Introducción. Los estudios sobre la corte. Interpretación de la corte de Felipe II". La corte de Felipe II, editado por José Martínez Millán. Madrid: Alianza Editorial, I999, pp. I3-36.

Mínguez, Víctor. La invención de Carlos II. Apoteosis simbólica de la Casa de Austria. Madrid: Centro de Estudios Europa Hispánica, 2013.

Mínguez, Víctor e Inmaculada Rodríguez Moya. Visiones de un imperio en fiesta. Madrid: Fundación Carlos de Amberes, 2016.

Mínguez, Víctor et al. La fiesta barroca. La corte del rey (1555-I808). Castelló: Editorial Universidad Jaume I, 2016.

---. La fiesta barroca. El reino de Valencia (1599-1802). Castelló: Editorial Universidad Jaume I, 2 oro.

---. La fiesta barroca. Los reinos de Nápoles y Sicilia (1535-I7I3). Castelló: Editorial Universidad Jaume I / Generalitat Valenciana, 2014.

---. La fiesta barroca. Los virreinatos americanos (I560-I808). Castelló: Editorial Universidad Jaume I / Universidad de las Palmas de Gran Canaria, 2012.

Monteagudo Robledo, María Pilar. La monarquía ideal. Imágenes de la realeza en la Valencia moderna. Valencia: Universidad de Valencia, I995.

Muir, Edward. Fiesta y rito en la Europa moderna. Madrid: Editorial Complutense, 2002.

Nieto Soria, José Manuel. Fundamentos ideológicos del poder real en Castilla (siglos XIIIXVI). Madrid: Eudema, I998.

---. Orígenes de la monarquía hispánica. Propaganda y legitimación. Madrid: Editorial Dykinson, I999.

Nieva Ocampo, Guillermo et al., coordinadores. El principe, la corte y sus reinos. Agentes $y$ prácticas de gobierno en el mundo bispano (ss. XIV-XVIII). Tucumán: Humanitas, Facultad de Filosofía y Letras de la Universidad Nacional del Tucumán, $20 r 6$. 
Noel, Charles. "La etiqueta borgoñona en la corte española. I547-I80o". Manuscrits: Revist d'Història Moderna, n. ${ }^{\circ}$ 22, 2004, pp. I39-160.

Nye, Joseph. Soft Power: The Means to Success in World Politics. Nueva York: Public Affairs, 2004.

Osorio, Alejandra. Inventing Lima. Baroque Modernity in Peru's South Sea Metropolis. S. 1.: Palgrave Macmillan, 2008.

---. "El rey en Lima. E1 simulacro y el ejercicio del poder en la Lima del diecisiete". Documento de trabajo, n. ${ }^{\circ}$ I40, serie Historia 27. Lima: Instituto de Estudios Peruanos, 2008. http://lanic.utexas.edu/project/laoap/iep/ddtı4o.pdf.

Pagden, Anthony. El imperialismo español y la imaginación politica: estudios sobre teoría social y politica europea e hispanoamericana (I5I3-I830). Madrid: Editorial Planeta, I99I.

---. Señores de todo el mundo. Ideologias del imperio en España, Inglaterra y Francia en los siglos XVI, XVII y XVIII. Barcelona: Editorial Península, I997.

Palacios Martín, Bonifacio. "Imágenes y símbolos del poder real en la Corona de Aragón”. El poder real de la Corona de Aragón (siglos XIV-XVI), vol. I. Zaragoza: Gobierno de Aragón, Departamento de Educación, Cultura y Deporte, I996, pp. $189-230$.

Palos, Joan-Lluis y Magdalena Sánchez. Dynastic Marriage and Cultural Transfers in Early Modern Europe. Nueva York: Routledge, 2016.

Pérez Samper, María Ángeles. "Imagen de la monarquía española en el siglo Xviı". Obradoiro de Historia Moderna, n. 20 ("Poder, imagen, opinión pública y propaganda en la Edad Moderna”), 20II, pp. I05-I39.

---. "La presencia del rey ausente: las visitas reales a Cataluña en la época moderna". Imagen del rey, imagen de los reinos. Las ceremonias públicas en la España moderna (I500-I814), dirigida por Agustín González Enciso y Jesús María Usunáriz. Pamplona: Ediciones Universidad de Navarra, ı999, pp. 63-ıı6.

Revel, Jacques. "La royauté sacreé: elements pour un debat". La royauté sacrée dans le monde chrétien. Colloque de Royaumont, mars 198, dirigido por Alain Boureau y Claudio Sergio Ingerflom. París: Ehess, I992, pp. 7-I7.

Rey, Hazas Antonio, Mariano Gutiérrez de la Campa y Pablo Esther Jiménez, coordinadores. La corte del Barroco. Textos literarios, avisos, manuales de corte, etiqueta y oratoria. Madrid: Ediciones Polifemo, 2016.

Río Barredo, María José del. "Felipe II y la configuración del sistema ceremonial de la monarquía hispánica”. Felipe II (I527-I598). Europa y la monarquía católica. Vol. I, tomo 2, dirigido por José Martínez Millán, I998, pp. 677-703. 
---. Madrid, urbs regia. La capital ceremonial de la monarquía católica. Madrid: Editorial Marcial Pons, 20oo.

---. "El ritual en la corte de los Austrias". La fiesta cortesana en la época de los Austrias, coordinado por María Luisa Lobato y Bernardo J. García García. Valladolid: Junta de Castilla y León, Consejería de Cultura y Turismo, 2003, pp. 17-34.

Rivero Rodríguez, Manuel. "Court Studies in the Spanish World”. The Court in Europe, coordinado por Marcelo Fantoni. Roma: Bulzoni Editore, 20I2, pp. I35-I48.

---. La edad de oro de los virreyes: el virreinato en la monarquía hispánica durante los siglos XVI y XVII. Madrid: Akal, 2oII.

---. "Reformismo y decadencia del modelo cortesano virreinal hispánico en el siglo xviII". La corte de los Borbones. Crisis del modelo cortesano, coordinado por J. Martínez Millán et al. Madrid: Polifemo, 2013, pp. 587-607.

Rodríguez de la Flor, Fernando. Barroco. Representación e ideología en el mundo bispánico. Madrid: Cátedra, 2002.

---. Emblemas: lecturas de la imagen simbólica. Madrid: Alianza Editorial, 1995.

Salazar Baena, Verónica. "Fastos monárquicos en el Nuevo Reino de Granada: entre los intereses reales y las pretensiones locales. Siglos Xvi-XVIII”. Tesis doctoral, Universidad de Barcelona, 20r3.

Serrano, Martín Eliseo. Muerte, religiosidad y cultura popular. Siglos XIII al XVIII. Zaragoza: Institución Fernando el Católico, I994.

Valenzuela Márquez, Jaime. Las liturgias del poder. Celebraciones litúrgicas y estrategias persuasivas en Chile colonial (I609-I709). Santiago de Chile: Centro de Investigaciones Diego Barros Arana / LOM Editores, 200I.

Van Goudover, Albert. "The Importance of the Soft Power in the Concept of Empires and Great Powers". Studia Europaea, n. ${ }^{\circ}$ I, 2010, pp. 5-26.

Varela, Javier. La muerte del rey. El ceremonial funerario de la monarquía española (I550I885). Madrid: Turner, I990.

Vigarello, George. "El cuerpo del rey". Historia del cuerpo. Tomo I. Del Renacimiento a la Ilustración, editado por Alain Corbain. Madrid: Taurus Historia, 2005, pp. 373-394. 